\title{
PEMBERIAN INISIASI MENYUSU DINI PADA BAYI BARU LAHIR
}

\author{
Arlin Adam ${ }^{1}$, Andi Alim², Novi Purnama Sari ${ }^{3}$ \\ ${ }^{1}$ Dosen Jurusan Promkes FKM UPRI Makasar \\ ${ }^{2}$ Dosen Jurusan Gizi Kesmas FKM UPRI Makasar \\ ${ }^{3}$ Fakultas Kesehatan Masyarakat UPRI Makassar
}

\begin{abstract}
Provision of Early Initiation of Breastfeeding (IMD) to newborns in Indonesia is still relatively more low. Early Initiation of Breastfeeding can increase potential success of exclusive breastfeeding for 6 months. Found $40 \%$ of infant deaths occur in the first month of life. The infant mortality can be reduced by up to $22 \%$ with action of Early Initiation Breastfeeding. This study aimed to analyze the influence of knowledge, support health, and social culture of the provision of Early Initiation of Breastfeeding newborn. This research was conducted at the General Hospital of Makassar to the entire population that has been doing deliveries, with a total sample of 100 respondents. Research shows that there is a relationship between the mother's knowledge by giving Early Initiation of Breastfeeding $(p=0.000)$. There is a relationship between support services to the administration of Early Initiation of Breast feeding $(\mathrm{p}=0.000)$. There was no relationship between the social and cultural perspectives giving Early Initiation of Breastfeeding $(\mathrm{p}=1,000)$. Enough knowledge about the provision of Early Initiation of Breastfeeding is a need for being able to reduce infant mortality. Health workers support the Early Initiation of Breastfeeding is an appropriate step to encourage mothers to give Early Initiation of Breastfeeding. Social effects of culture against early initiation of breastfeeding sometimes become an obstacle to the provision of Early Initiation of Breastfeeding.
\end{abstract}

\section{Keyword: IMD, Knowledge, Service Support, Social Cultural.}

\section{PENDAHULUAN}

Berdasarkan penelitian WHO (World Health Organization) tahun 2013, di enam negara berkembang resiko kematian bayi antara usia $9-12$ bulan meningkat $40 \%$ jika bayi tersebut tidak disusui. Untuk bayi berusia dibawah 2 bulan, angka kematian ini meningkat menjadi $48 \%$ sekitar $40 \%$ kematian balita terjadi satu bulan pertama kehidupan bayi. Inisiasi Menyusu Dini (IMD) dapat mengurangi $22 \%$ kematian bayi 28 hari, berarti inisiasi menyusu dini (IMD) mengurangi kematian balita $8,8 \%$. Namun, di Indonesia hanya $8 \%$ ibu yang memberikan ASI eksklusif kepada bayinya sampai berumur 6 bulan dan hanya $4 \%$ bayi disusui ibunya dalam waktu satu jam pertama setelah kelahirannya. Padahal sekitar 21.000 kematian bayi baru lahir (usia dibawah 28 hari) di Indonesia dapat dicegah melalui pemberian ASI pada satu jam pertama setelah lahir.

Angka kematian bayi dan balita di Sulawesi Selatan dapat digambarkan, antara lain persentase cakupan pemberian ASI eksklusif $(57,48 \%$ pada tahun 2013 dan 57,05\% pada tahun 2014) dan lain-lain. Untuk data tahun 2013 persentase, cakupan pemberian ASI eksklusif meningkat menjadi $77,18 \%$ (Kusumawati, 2013).

Inisiasi Menyusu Dini atau Permulaan Menyusu Dini adalah bayi mulai menyusu sendiri segera setelah lahir. Sebenarnya bayi manusia juga seperti mamalia lain mempunyai kemampuan untuk menyusu sendiri. Asalkan dibiarkan kontak kulit bayi dengan kulit ibunya, setidaknya selama satu jam segera setelah lahir. Cara melakukan inisiasi menyusu dini ini dinamakan the breast crawl atau merangkak mencari payudara sendiri (Irawan, 2013).

Pada hari pertama sebenarnya bayi belum memerlukan cairan atau makanan, tetapi pada usia 30 menit harus di susukan pada ibunya, bukan untuk pemberian nutrisi tetapi untuk belajar menyusu atau membiasakan menghisap puting susu dan juga guna mempersiapkan ibu untuk mulai memproduksi ASI. Apabila bayi tidak menghisap puting susu pada setengah jam setelah persalinan, Prolaktin (hormon pembuat ASI) akan turun dan sulit merangsang prolaktin sehingga ASI baru akan keluar pada hari ketiga atau lebih dan memperlambat pengeluaran kolostrum (Roesli, 2010).

Manfaat Inisiasi Menyusu Dini, bayi dan ibu menjadi lebih tenang, tidak stres, 
pernafasan dan detak jantung lebih stabil, dikarenakan oleh kontak antara kulit ibu dan bayi. Sentuhan, emutan dan jilatan bayi pada puting susu ibu akan merangsang pengeluaran hormon oxytosin yang menyebabkan rahim berkontraksi sehingga mengurangi perdarahaan ibu dan membantu pelepasan plasenta. Bayi juga akan terlatih motoriknya saat menyusu, sehingga mengurangi kesulitan posisi menyusu dan mempererat hubungan ikatan ibu dan anak (JNKPK-KR, 2013).

Dengan adanya upaya kesehatan ibu bersalin maka peran tenaga kesehatan sangatlah penting, karena bisa memberikan keyakinan dan kepercayaan kepada ibu bersalin. Tenaga kesehatan akan sangat berpengaruh dalam pelaksanaan IMD yang dilakukan sesaat setelah bayi lahir (Notoatmodjo 2010).

Edukasi sangat berpengaruh terhadap perubahan pengetahuan. Perilaku menyusui bayi sendiri dianggap sebagian orang sebagai tingkah laku yang tradisional. Pengetahuan ibu tentang IMD sangat penting. Banyak ibu tidak mengetahui tentang manfaat IMD. Seringkali para ibu memiliki pemahaman yang tidak benar, misalnya tidak perlu meneteki bayi karena ASI belum keluar atau karena air susu yang keluar pertamakali dan berwarna kuning adalah kotoran dan basi. Hal lainya yang membuat pemberian ASI tertunda misalnya ibu merasa haus dan perlu istirahat dulu kerena lelah, masih merasa sakit, atau menganggap bayi perlu dimandikan terlebih dahulu (Notoatmodjo 2010).

Keberhasilan pemberian ASI eksklusif kepada bayi sampai umur enam bulan bergantung pada keberhasilan praktik inisiasi menyusu dini, juga sangat bergantung pada factor social. Peran faktor sosial budaya adalah dalam membentuk, mengatur, dan mempengaruhi tindakan dan kegiatan dalam pemberian ASI. Adakalanya faktor sosial budaya dapat mendukung pemberian ASI atau sebaliknya adakalah faktor social budaya menghindari pemberian ASI.

Upaya meningkatkan pemberian ASI sedini mungkin di Indonesia hingga saat ini masih banyak menemui kendala. Permasalahan yang utama adalah faktor kurangnya pengetahuan, sosial budaya, kesadaran akan pentingnya ASI untuk kesehatan anak, pelayanan kesehatan dan petugas kesehatan yang belum sepenuhnya mendukung program peningkatan penggunaan ASI.
Keberhasilan pembangunan nasional suatu bangsa ditentukan oleh ketersediaan sumber daya manusia yang berkualitas. Kekurangan gizi yang terjadi pada individu dapat merusak kualitas sumber daya manusia. Kejadian kekurangan gizi sering terluput dari pengamatan biasa, akan tetapi secara perlahan dapat berakibat pada tingginya angka kematian ibu, angka kematian bayi, angka kematian balita serta rendahnya umur harapan hidup (Kusumawati, 2013). Berdasarkan latar belakang diatas, maka penulis tertarik untuk meneliti tentang hubungan pemberian inisiasi menyusu dini pada bayi baru lahir diruang bersalin Rumah Sakit Umum Daerah Kota Makassar.

\section{METODE \\ Jenis Penelitian}

Penelitian ini merupakan observasi analitik yaitu penelitian yang menjelaskan adanya hubungan antara variabel melalui pengujian hipotesa. Sedangkan waktu penelitian dengan metode survey dan wawancara dengan kuesioner. Berdasarkan waktu penelitian adalah potong lintang (cross sectional) karena mempelajari korelasi antar variabel sebab dengan akibat.

\section{Waktu dan Lokasi Penelitian}

Penelitian ini dilakukan di Rumah Sakit Umum Daerah Makassar Provinsi Sulawesi Selatan dimulai pada tanggal 25 April sampai dengan 24 Juni tahun 2016

\section{Populasi dan Sampel}

Populasi dalam penelitian ini adalah seluruh ibu yang telah melahirkan pervaginam dengan bayi sehat yang ada di Rumah Sakit Umum Daerah Kota Makassar yang berjumlah 135 orang. Sampel dalam penelitian ini adalah sebagian yang diambil dari keseluruhan objek yang diteliti dan dianggap mewakili, dalam penelitian ini adalah semua ibu bersalin pervaginam dengan bayi sehat di Rumah Sakit Umum Daerah Kota Makassar.

Besar sampel yang diambil dengan menggunakan rumus:

$$
\mathrm{n}=\quad \begin{gathered}
\mathrm{N} \cdot \mathrm{Z}^{2} \cdot \mathrm{p} \cdot \mathrm{q} \\
\mathrm{d}^{2} \cdot(\mathrm{N}-1)+\mathrm{Z}^{2} \cdot \mathrm{p} \cdot \mathrm{q}
\end{gathered}
$$

Diperoleh besar sampel sebanyak 100 orang. Pengambilan sampel dilakukan dengan cara simple random sampling. 


\section{Teknik Pengumpulan Data}

Teknik pengumpulan data yang digunakan adalah kuesioner dan observasi. Kuesioner adalah suatu daftar pertanyaan yang dibutuhkan dari masing-masing responden yang menjadi sampel sebanyak ibu yang bersalin. Observasi adalah penelitian awal atau pra penelitian dengan maksud untuk mengidentifikasi berbagai permasalahan-permasalahan yang ada dilapangan yang ada relevansinya dengan penelitian ini.

Analisa data
Analisis data dilakukan dengan menggunakan Uji Chi-Square $\left(\mathrm{X}^{2}\right)$ dengan tingkat signifikasi alfa $(\alpha=0,05)$, taraf kepercayaan $95 \%$ dan derajat kepercayaan $\mathrm{df}=1$.

\section{Penyajian Data}

Data yang telah diolah disajikan dalam bentuk tabel kemudian dinarasikan dengan menggunakan program Microsoft excel dan Microsoft word.

HASIL PENELITIAN

Karakteristik Responden

Tabel 1. Distribusi Karakteristik Responden di Rumah Sakit Umum Daerah Makassar

\begin{tabular}{lcclcc}
\hline \multicolumn{1}{c}{ Variabel penelitian } & $\mathbf{n}$ & $\mathbf{\%}$ & Variabel Penelitian & $\mathbf{n}$ & $\boldsymbol{\%}$ \\
\hline Umur & & & Tingkat Pendidikan & & \\
$26-30$ & 42 & 42 & Akademi/S1 & 6 & 6 \\
$21-25$ & 39 & 39 & SLTA & 52 & 52 \\
$18-20$ & 15 & 15 & SLTP & 37 & 37 \\
$31-35$ & 3 & 3 & SD & 3 & 3 \\
$>35$ & 1 & 1 & Tidak Sekolah & 2 & 2 \\
$\quad$ Jumlah & 100 & 100 & Jumlah & 100 & 100 \\
Pemberian IMD & & & Pengetahuan & 77 & 77 \\
$\quad$ Tidak Dilakukan & 81 & 81 & Kurang & 23 & 23 \\
$\quad$ Dilakukan & 19 & 19 & Cukup & 100 & 100 \\
$\quad$ Jumlah & 100 & 100 & Jumlah & & \\
Dukungan Tenaga Kesehatan & & & Sosial Budaya & 68 & 68 \\
$\quad$ Tidak & 76 & 76 & Tidak Percaya & 32 & 32 \\
$\quad$ Ya & 24 & 24 & Percaya & 100 & 100 \\
$\quad$ Jumlah & 100 & 100 & Jumlah &
\end{tabular}

Berdasarkan tabel 1, distribusi responden berdasarkan umur yaitu pada umur 26-30 sebanyak 42 responden (42\%), sedangkan pada umur 21 - 25 sebanyak 39 responden (39\%) dan pada umur 18 - 20 sebanyak 15 responden (15\%). Distribusi responden berdasarkan tingkat pendidikan responden yaitu 52 responden $(52 \%)$ mengenyam pendidikan SLTA, sebanyak 3 responden $(37 \%)$ mengenyam pendidikan SLTP, pada tingkat Akademi/S1 Sebanyak 6 responden $(6 \%)$, yang tingkat pendidikan sekolah dasar sebanyak 3 responden $(3 \%)$ dan yang tidak bersekolah 2 responden (2\%).

Berdasarkan dari pemberian Inisiasi Menyusu Dini sebanyak 81 responden $(81 \%)$ tidak melakukan Inisiasi Menyusu Dini, sedangkan 19 responden (19\%) melakukan Inisiasi Menyusu Dini. Responden yang memiliki pengetahuan yang cukup tentang IMD (Inisiasi Menyusu Dini) adalah sebanyak 23 respoden $(23 \%)$ dan responden yang memiliki pengetahuan kurang lebih kecil yaitu 77 responden (77\%). Berdasarkan dukungan tenaga kesehatan, sebanyak 76 responden (76\%) tidak mendapatkan dukungan tenaga kesehatan, sedangkan sebanyak 24 responden (24\%) mendapatkan dukungan tenaga kesehatan. Berdasarkan sosial budaya terdapat 68 responden $(68 \%)$ tidak percaya, sedangkan sebanyak 32 responden (32\%) percaya.

Hasil Analisa Hubungan Variabel

Berdasarkan Tabel. 2 menunjukkan hubungan pengetahuan ibu dengan Inisiasi Menyusu Dini. Responden dengan pengetahuan cukup namun tidak memberikan Inisiasi Menyusu Dini sebesar 8 (34,78\%) serta yang memberikan Inisiasi Menyusu Dini sebanyak 15 (65,22\%), sedangkan yang memiliki pengetahuan kurang dan tidak memberikan Inisiasi Menyusu Dini sebanyak 73 (94,81\%) 
dan yang memberikan Inisiasi Menyusu Dini sebanyak $4(5,19 \%)$. Berdasarkan hasil uji statistik diperoleh nilai $\mathrm{p}=0.000<\alpha=0,05$, hal ini berarti bahwa Ha diterima dan Ho ditolak atau ada hubungan antara pengetahuan ibu dengan Inisiasi Menyusu Dini.

Tabel 2. Hubungan Pengetahuan Ibu, Dukungan Tenaga Kesehatan dan Sosial Budaya dengan Inisiasi Menyusu Dini Di Rumah Sakit Umum Daerah Makassar

\begin{tabular}{|c|c|c|c|c|c|c|c|}
\hline \multirow{3}{*}{ Variabel Penelitian } & \multicolumn{4}{|c|}{ Inisiasi Menyusu Dini } & & & \multirow{3}{*}{$\mathbf{p}$} \\
\hline & \multicolumn{2}{|c|}{$\begin{array}{c}\text { Tidak } \\
\text { dilakukan }\end{array}$} & \multicolumn{2}{|c|}{ Dilakukan } & \multicolumn{2}{|c|}{ Total } & \\
\hline & $\mathbf{n}$ & $\%$ & $\bar{n}$ & $\%$ & $\bar{n}$ & $\%$ & \\
\hline \multicolumn{8}{|l|}{ Pengetahuan } \\
\hline Kurang & 73 & 94,81 & 4 & 5,19 & 77 & 100 & \multirow{3}{*}{0,000} \\
\hline Cukup & 8 & 34,78 & 15 & 65,22 & 23 & 100 & \\
\hline Total & 81 & 81,00 & 19 & 19,00 & 100 & 100 & \\
\hline \multicolumn{8}{|c|}{ Dukungan Tenaga Kesehatan } \\
\hline Tidak & 72 & 94,74 & 4 & 5,26 & 76 & 100 & \multirow{3}{*}{0,000} \\
\hline $\mathrm{Ya}$ & 9 & 37,50 & 15 & 62,50 & 24 & 100 & \\
\hline Total & 81 & 81,00 & 19 & 19,00 & 100 & 100 & \\
\hline \multicolumn{8}{|l|}{ Sosial Budaya } \\
\hline Percaya & 26 & 81,25 & 6 & 18,75 & 32 & 100 & \multirow{3}{*}{1,000} \\
\hline Tidak Percaya & 55 & 80,88 & 13 & 19,12 & 68 & 100 & \\
\hline Total & 81 & 81,00 & 19 & 19,00 & 100 & 100 & \\
\hline
\end{tabular}

Responden yang tidak mendapatkan dukungan tenaga kesehatan dan tidak memberikan IMD sebesar 72 (94,74\%) dan memberikan Inisiasi Menyusu Dini sebesar 4 $(5,26 \%)$ sedangkan yang mendapat dukungan tenaga kesehatan dan tidak memberikan IMD sebesar $9(37,50 \%)$ dan memberikan IMD sebesar $15(62,50 \%)$. Berdasarkan hasil uji statistic diperoleh nilai $p=0,000<\alpha=0,05$, hal ini berarti bahwa Ha diterima dan Ho ditolak atau adanya hubungan antara dukungan tenaga kesehatan dengan pemberian inisiasi menyusu dini.

Responden yang tidak percaya dan tidak melakukan Inisiasi Menyusu adalah sebesar $55(80,88 \%)$ dan yang melakukan Inisiasi Menyusu Dini adalah sebesar 13 $(19,12 \%)$ sedangkan responden yang percaya dan tidak melakukan Inisiasi Menyusu Dini adalah sebesar $26 \quad(81,25 \%)$ dan yang melakukan Inisiasi Menyusu Dini adalah sebesar $6(18,75 \%)$. Berdasarkan hasil uji statistic diperoleh nilai $\mathrm{p}=1,000>\alpha=0,05$, hal ini berarti bahwa Ho diterima dan $\mathrm{Ha}$ ditolak atau tidak adanya hubungan antara sosial budaya dengan pemberian inisiasi menyusu dini.

\section{PEMBAHASAN}

\section{Hubungan Pengetahuan dengan Pemberian} Inisiasi Menyusu Dini

Dari hasil penelitian yang telah dilakukan bahwa pengetahuan ibu mengenai Inisiasi Menyusu Dini menunjukkan nilai yang kurang, hal tersebut mempengaruhi pada pemberian Inisiasi Menyusu Dini pada bayi yang baru saja melewati masa bersalin. Inisiasi menyusu dini merupakan tahapan awal dimana bayi yang telah melewati masa bersalin akan mengenal asupan berupa air susu ibu. pemberian inisiasi menyusu dini juga dapat memberikan cakupan gizi yang besar bagi bayi, dikarenakan kandungan air susu pada payudara ibu yang pertama kali keluar adalah kolostrum yang sangat bermanfaat bagi bayi khususnya sebagai pembentukan imunitas tubuh bayi.

Kurangnya pengetahuan ibu tentu akan mempengaruhi tindakan ibu untuk memberikan Inisiasi Menyusu Dini. Hal ini terjadi karena semakin tinggi pengetahuan akan semakin mudah juga untuk memberikan informasi dan mengarahkan ibu untuk memberikan IMD.

Pengetahuan adalah pola yang telah tersusun secara sistematis melalui pengalaman indrawi yang tertanam dalam ingatan setiap orang. pengetahuan harusnya membentuk pola 
perilaku dimana seseorang dapat bertindak dengan memikirkan aspek positif dan negatif yang ada. terbentuknya pengetahuan pada seseorang dipengaruhi oleh lingkungan dimana pada wilayah tersebut senantiasa membahas atau membicarakan argument yang menyangkut pada pola pengetahuan itu sendiri.

Penelitian yang sejalan dijelaskan oleh Winda (2003), dimana dalam pembahasannya menjelaskan bahwa semakin tinggi pengetahuan maka semakin tinggi pula kesadaran atau tindakan yang dilakukan, sebaliknya jika pengetahuan rendah maka akan berpengaruh pada tidak maksimalnya pemberian Inisiasi Menyusu Dini.

Berbeda dengan penelitian yang dilakukan oleh Ansar Said (2005) tidak ada hubugan yang terjadi, jika pengetahuan menunjukkan nilai cukup maka ibu akan memberikan Inisiasi Menyusu Dini. bisa jadi ibu yang memiliki pengetahuan cukup tidak melakukan Inisiasi Menyusu Dini disebabkan oleh aktifitas kerja yang sangat padat atau ada hal lain yang menyebabkan sehingga ibu tidak memberikan Inisiasi Menyusu Dini.

\section{Hubungan Dukungan Petugas Kesehatan dengan Pemberian Inisiasi Menyusu Dini}

Dari hasil penelitian ini menunjukan bahwa sebagian besar responden yang tidak mendapatkan dukungan petugas kesehatan terkait pelaksanaan inisiasi menyusu dini tidak melaksanakan Inisiasi Menyusu Dini. Sedangkan pada responden yang mendapatkan dukungan tenaga kesehatan sebagian besar melaksanakan Inisiasi Menyusu Dini. Penelitian ini sejalan dengan penelitian yang dilakukan oleh yendra (2011), Suhartatik dkk (2013) yang menyatakan bahwa ada hubungan yang signifikan antara dukungan tenaga kesehatan dengan pemberian Inisiasi Menyusu Dini.

Petugas kesahatan penolong persalinan merupakan kunci utama keberhasilan IMD karena dalam waktu tersebut peran dan dukungan penolong persalinan masih sangat dominan. Apabila penolong persalinan memfasilitasi ibu untuk segera memeluk bayinya maka interaksi ibu dan bayi diharapkan segera terjadi. Dengan pelaksanaan IMD, ibu semakin percaya diri untuk tetap memberikan ASInya sehingga tidak merasa perlu untuk memberikan makanan atau minuman kepada bayinya dan bayi akan merasa nyaman menempel pada payudara ibu dan tenang dalam pelukan ibu segera setelah lahir. Oleh karena itu, keterampilan dalam menerapkan tatalaksana Inisiasi Menyusu Dini dengan benar memang sudah menjadi hal yang mutlak yang harus dimiliki oleh petugas kesehatan yang menolong persalinan. Ibu maupun suami yang mendampingi akan mengikuti apa saja yang disarankan dan dilakukan oleh petugas kesehatan pada saat persalinan. Apabila petugas kesehatan tidak terampil dalam penerapan langkah-langkah dalam IMD maka kemungkinan besar Inisiasi Menyusu Dini akan gagal dilaksanakan pasca persalinan.

Kendala utama yang ditemukan di lapangan yang berhubungan dengan pelaksanaan Inisiasi Menyusu Dini antara lain, belum optimalnya komitmen Rumah Sakit dan penolong persalinan untuk selalu melakukan Inisiasi Menyusu Dini pada bayi baru lahir, gempuran promosi susu formula dengan imingiming bonus yang begitu besar kepada petugas kesehatan. Faktor ibu bersalin juga berperan pada kegagalan Inisiasi Menyusu Dini antara lain rendahnya pengetahuan ibu tentang Inisiasi Menyusu dini. Oleh karena itu diharapkan petugas kesehatan lebih bijak dalam memberikan penyuluhan dan pengarahan tentang IMD jangan malah petugas kesehatan sendiri yang memotivasi ibu untuk memberikan susu formula.

Hasil penelitian di atas sejalan dengan hasil penelitian yang dilakukan oleh Tarigan (2012), bahwa dukungan tenaga kesehatan yang menolong persalinan sebagai faktor penguatuntuk pemberian ASI Eksklusif kepada bayi. Juga penelitian yang dilakukan oleh Ratri (2000), bahwa ada hubungan bermakna antara pemberian ASI pertama kali dengan pemberian nasehat ASI yang diterimasaat pemeriksaan kehamilan. Ibu yang menerima nasehat tentang ASI memiliki rata-rata pemberian ASI pertama kali paling cepat yaitu 26, 25 jam setelah lahir.

\section{Hubungan Sosial Budaya dengan Pemberian Inisiasi Menyusu Dini}

Dari hasil penelitian yang telah dilakukan terkait dengan pengaruh sosial budaya yang terjadi terhadap pemberian Inisiasi Menyusu Dini bahwa masyararakat tidak terpengaruh akan hal tersebut. Pada umumnya masyarakat saat ini tidak terpengaruh lagi oleh adanya sosial budaya yang mengatakan tentang mitologi mengenai Inisiasi Menyusu Dini. Masyarakat lebih cenderung berfikir modern dan tidak mempermasalahkan lagi larangan- 
larangan yang menjadi penghambat dalam pemberian inisiasi menyusu dini.

Pada dasarnya sosial budaya akan mempengaruhi susunan struktur di masyarakat itu sendiri, dikarenakan segala aspek yang ada diwilayah tersebut akan terserap secara sendiri sehingga akan di adopsi oleh masyarakat itu secara turun menurun. Mengubah dari suatu sosial budaya tentang IMD di masyarakat khusunya pada ibu untuk melakukan IMD dengan memberikan pendidikan non formal seperti penyuluhan tenaga kesehatan pada ibu hamil atau pada ibu yang melahirkan tentang manfaat IMD, secara bertahap akan mengubah kepercayaan ibu menyusui atau ibu hamil tentang IMD.

Meskipun ASI sangat penting peranannya bagi bayi, sang ibu tidak begitu saja bias menyusui terutama bagi mereka yang tinggal di daerah desa, pinggir kota, atau pedalaman, dimana informasi tentang asi dan menyusui tidak bias diankses begitu saja. Kalaupun ada informasi yang benar masih harus berhadapan dengan berbagai mitos yang berkembang dimasyarakat tentang ASI dan ibu menyusui. Mitos-mitos tersebut telah berkembang sekian lama, diwariskan secara turun-temurun, dan sebagian besar tidak bisa dibuktikan kebenarannya bahkan cenderung menyesatkan. Salah satu mitos yang terjadi dimasyarakat yaitu ASI bias merusak kulit bayi, karena anggapan ini telah masyarakat, sang ibu yang mendapati kulit bayinya terkena ASI akan buru-buru menjilatnya atau membersikannya dengan apa saja yang ada di dekatnya. Jika terlambat diyakini akan membuat kulit bayi memerah, dan bayi akan merasa gatal/panas. Jika dibersikan untuk tujuan menjaga kebersihan tentu hal ini dianjurkan. Bias dilakukan dengan menggunakan kapas yang dibasahi air hangat. Tapi bila karena ketakutan kulit bayinya akan rusak, itu adalah anggapan yang keliru. ASI tidak akan merusak kulit. pada bayi memang ada penyakit kulit yang disebut atopic dermatitis atau sering disebut milk dermatitis. Biasanya mneyerang daerah pipi, tapi penyebabnya bukanlah ASI atau hasil kontak kulit dengan susu. Kemungkinan besar hal ini terjadi karena sebelumnya memang sudah ada kelainan kulit pada bayi tersebut.

Sosial budaya yang mendukung pemberian IMD dapat dipengaruhi oleh pengetahuan, karena kebiasaan dalam konteks ini adalah kebiasaan ibu meyusui bayi dipengaruhi oleh pengetahuan. Kebiasaan- kebiasaan atau social budaya yang tidak mendukung pemberian IMD diubah dengan adanya pengetahuan, karena sosial budaya yang ada dimasyarakat tentang Pemberian ASI seperti ASI yang pertama kali keluar di adalah kotoran namun ASI yang pertama keluar atau yang biasa disebut kolostrum adalah ASI yang paling baik karena kandungan kolostrumnya. Kolostrum ini akan keluar hingga hari kelima/tujuh. kolostrum ini mengandung zat putih telur (protein) yang kadarnya tinggi terutama kandungan zat anti infeksi/ daya tahan tubuh. Sedangkan kadar laktosa dan lemaknya rendah sehingga mudah dicerna. Jadi bila kolostrum berwarna jernih kekuningan ini dibuang, bayi tidak atau kurang mendapatkan zat-zat yang melindungi dari infeksi.

Walaupun pada masyarakat tradisional pemberian ASI bukan merupakan permasalahan yang besar karena pada umumnya ibu memberikan bayinya ASI, namun permasalahan adalah pola pemberian ASI yang tidak sesuai dengan konsep medis sehingga menimbulkan dampak negatif pada kesehatan dan pertumbuhan bayi. Disamping pola pemberian ASI yang salah, kualitas ASI juga kurang. Hal ini disebabkan banyaknya pantangan terhadap makanan yang di komsumsi si ibu baik pada saat hamil maupun sesudah melahirkan. Sebagai contoh, pada masyarakat tanjung pura ibu yang menyusui pantang untuk mengkonsumsi bayam, ikan laut, atau sayur nangka.

Pada beberapa masyarakat tradisional Indonesia kita bisa melihat konsepsi budaya yang terwujud dalam perilaku berkaitan dengan pola pemberian makanan pada bayi yang berbeda dengan konsepsi kesehatan yang moderen. Dalam penelitian yang dilakukan oleh Muchtar Ali (2004) menyebutkan bahwa saat ini masyarakat telah berfikir modern sehingga pengaruh sosial budaya dapat di filter sedemikian rupa.

\section{KESIMPULAN}

Terdapat hubungan yang signifikan antara pengetahuan ibu dengan pemberian IMD. Terdapat hubungan yang signifikan antara dukungan petugas kesehatan dengan pemberian IMD. Tidak ada hubungan antara sosial budaya dengan IMD.

Disarankan pada ibu yang memiliki pengetahuan kurang agar sesering mungkin untuk mencari informasi mengenai IMD, ibu juga harus senantiasa aktif untuk menanyakan 
pada ahli yang mengetahui tentang manfaat IMD. Jika hal tersebut dilakukan maka secara otomatis ibu akan memberikan IMD kepada bayinya.

Bagi Petugas layanan kesehatan seharusnya lebih aktif dalam memberikan informasi mengenai IMD, disamping itu hal yang sangat penting harus dilakukan adalah petugas harus mendukung Inisiasi Menyusu Dini pada ibu. Bagi Ibu yang masih terpengaruh demgan nilai-nilai sosial budaya agar dapat lebih dewasa dalam menyikapi segala aspek yang dapat menghambat pemberian IMD.

\section{DAFTAR PUSTAKA}

Ali Muchtar. (2004). Pengembangan Berpikir dan Nilai dalam Pendidikan IPS. Gelar Pustaka Mandiri. Bandung.

Irawan. (2013). Inisiasi Menyusui Dini Tertunda Meningkatkan Resiko Kematian Neonatal (jurnal) vol 117 No 31 hal E380-e386.

JNPK-KR. (2013). Pelatihan Asuhan Persalinan Normal \& Inisiasi Menyusu Dini. Jakarta.

Kusumawati, Anita. (2013). Hubungan Antara Pengetahuan Ibu Tentang Imd Dengan sikap Inisiasi Menyusu Dini Di Rb Harapan Bunda Pajang Surakarta Tahun 2010. Surakarta: Program Studi Diploma IV Kebidanan Universitas Sebelas Maret.

Notoatmodjo, Soekidjo. (2010). Promosi Kesehatan dan Ilmu Perilaku. Jakarta; PT. Rineka Cipta.

Notoatmodjo, Soekidjo. (2010). Metodologi Penelitian Kesehatan. Jakarta. Rineka Cipta.
Ratri, C. (2000). Faktor-Faktor yang Berhubungan dengan Pemberian ASI Pertama Kali di Purwakarta Jawa Barat tahun 1998 (Analisa Data Sekunder Pengembangan Survei Cepat Untuk Menilai Kualitas Pelayanan KIA di DT II). Skripsi. Depok: Fakultas Kesehatan Masyarakat Universitas Indonesia.

Roesli U. (2010). Inisiasi Menyusui Dini plus ASI Eksklusif. Jakarta: Pustaka Bunda.

Suhartatik, dkk. (2013). Faktor-faktor yang berhubungan dengan pelaksanaan Inisiasi Menyusui Dini (IMD) di rumah Bersalinn Srikandi Kota Kendari. Jurnal Volume 1 Nomor 4 Tahun 2012 Hal 1-7. STIKES Nani Hasanuddin. Makassar. Diakses Tanggal 4 Juli 2016.

Taringan, I. (2012). Pengetahuan dan Sikap Perilaku Ibu Dan Bayi Terhadap Pemberian ASI Ekslusif (Knowledge, Attitude and Behavior of The Mother of The Baby To The Breast Feeding Exclusively). Jakarta: Pusat Humaniora, Kebijakan Kesehatan Dan Pemberdayaan Masyarakat, Badan Penelitian Dan Pengembangan Kesehatan, Kementerian Keseharan RI.

Yendra. (2011). Hubungan Dukungan Sosial dengan Pelaksanaan Inisiasi Menyusui Dini di Wilyah Kerja Puskesmas Lubuk Buaya Kota Padang Tahun 2011, Skripsi, Fakultas Keperawatan Universitas Andalas. Diakses Tanggal 4 Juli 2016.

WHO (World Health Organization). (2013). Bresasfeeding. C2013: cited 4 Juli 2016. 